\title{
Mixing Ratio Optimization of Silkworm, Mealworm, and White Grub Using Response Surface Methodology
}

\author{
So-Young Lee ${ }^{1}$, Myung-Ryun $\mathrm{Han}^{2}$, Ae-Jung Kim ${ }^{3 *}$ \\ ${ }^{1}$ Department of Medium Therapy, Graduate School of Alternative Medicine, Kyonggi University, Seoul, Korea \\ ${ }^{2}$ Department of Baking Science \& Technology, Hyejeon College, Hongsung-gun, Chungchengnam-do, Korea \\ ${ }^{3}$ Department of Nutrition Therapy, Graduate School of Alternative Medicine, Kyonggi University, Seoul, Korea
}

"Corresponding author: Ae-Jung Kim, Department of Nutrition Therapy, Graduate School of Alternative Medicine, Kyonggi University, 24, Kyonggidae-ro, 9-gil, Seodaemun-gu, Seoul 03746, Korea Tel.: +82 23905044 Fax: +82 23905078

Email: aj5249@naver.com

Received November 15, 2021

Revised November 26, 2021

Accepted December 06, 2021

Published December 30, 2021

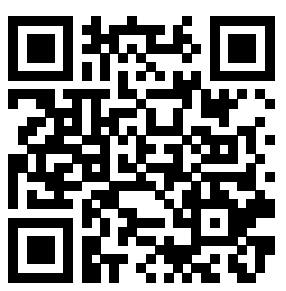

\begin{abstract}
Purpose: In this study, the optimal mixing ratio of total branched-chain amino acid (BCAA) content, total unsaturated fatty acid content, antioxidant activities, and enzyme activities of silkworm, mealworm, and white grub, which are alternative protein sources, was derived using response surface analysis. Method: Silkworm, mealworm, and white grub were the independent variables, and total BCAA content, total unsaturated fatty acid content, total polyphenol content, total flavonoid content, ABTS radical scavenging activity, $\alpha$-glucosidase inhibitory activity, and ACE inhibitory activity were used as the dependent variables to determine the optimal mixing ratio. Result: The optimal mixing ratio for total BCAA content, total unsaturated fatty acid content, antioxidant activities, and enzyme activities derived from the response surface analysis was silkworm $\left(X_{1}\right) 2.998$ : mealworm $\left(X_{2}\right) 0.623$ : white grub $\left(X_{3}\right)$ 1.983. At this ratio, the total BCAA content was $0.52 \mathrm{~g}$, the total unsaturated fatty acid content was $0.44 \mathrm{~g}$, the total polyphenol content was $67.02 \mathrm{mg} \mathrm{TAE} / \mathrm{g}$, the total flavonoid content was $35.58 \mathrm{mg} \mathrm{QE} / \mathrm{g}$, the ABTS radical scavenging activity was $95.61 \%$, the $\alpha$-glucosidase inhibitory activity was $37.79 \%$, and the ACE inhibitory activity was $95.25 \%$. Conclusion: It is expected that the optimal mixing ratio of silkworm, mealworms, and white grub derived in this study can be used to develop products for the management of various chronic diseases.
\end{abstract}

Keywords: Insect food, Response surface analysis, Antioxidant activity, $\alpha$-Glucosidase inhibitory activity, ACE inhibitory activity

\section{Introduction}

곤충(insect)은 동물계의 70\%를 차지하는 생물군(Evans et al., 2017)으로 남극의 만년설, 끓는 온천수, 깊은 동굴, 심해 등 지구의 모든 곳에서 서식하는데, 80 만 종류와 1 천 경의 개체 수가 있는 것으 로 추정된다(Youn et al., 2012).

그중 곤충식품(insect food)은 인간이 음식으로 만들어 섭취하는 식량자원(Bogueva et al., 2019) 또는 가축이나 애완동물의 먹이로 제공되는 식용자원(Chung et al., 2013a)을 의미한다.

역사적으로 인류는 곤충을 음식으로, 약용으로 사용해 왔으며(Lee et al., 2019). 최근에는 대체단백질의 급원으로 곤충식품이 재조명 되고 있으며, 농촌진흥청, 농림축산식품부, 한국곤충산업협회 등에
서 다양한 연구가 이루어지고 있다(Seo \& Ryu, 2019).

우리나라에서 식용으로 허용하고 있는 곤충식품으로는 유충 번 데기, 백강잠, 벼메뚜기, 갈색거저리 유충, 흰점박이꽃무지, 장수풍 뎅이 유충, 쌍별귀뚜라미, 아메리카왕거저리 유충 총 8종류가 있다 (Kim et al., 2020).

누에(Bombyx mori L.)는 신농본초경(神農本草經), 본초강목(本草 綱目), 동의보감(東醫寶鑑) 등의 고(古)서에 고혈압, 당뇨 및 불면증 개선에 효과가 있다고 기록되어 있다(Choi et al., 2015). 누에는 단 백질, 지방산, 필수 아미노산 및 불포화지방산의 함량이 높아 간장질 환과, 혈액순환 개선을 위한 기능성 식품의 소재로 이용되고 있다(Yu et al., 2008).

밀웜(Tenebrio molitor, mealworm)은 대두에 비해 필수 아미노 
산함량이 높고, 육류에 비해 불포화지방산 함량이 높아 기능성 식품 소재로 이용가치가 높다(Hwang et al., 2015; Pihlanto-Leppälä, 2000; Bovera et al., 2015).

굼벵이(Protaetia brevitarsis)는 조단백질 $57.86 \%$, 올레익산 $61.10 \%$, 철분 $174.6 \mathrm{mg}$ 을 함유하고 있다. Baek et al. (2017)은 세 포 분화, 근육의 강화 및 간 질환의 예방에 도움이 된다고 보고하였 다.

유엔식량농업기구(FAO)에서는 지구의 온난화로 인한 식량난을 해 결하기 위해 곤충식품을 섭취할 것을 제안하였다(van Huis et al., 2013).

곤충은 가축에 비해 생애주기가 짧아서 저비용으로 사육이 가능하 며(Chung et al., 2013a), 온실가스의 방출이 적어 생태계를 보존하 고, 환경을 보호할 수 있는 장점이 있다(Arsenault \& Brown, 2017). 영양학적으로는 필수아미노산의 함량이 높아(Chong et al., 2017) 근육량의 감소가 시작되는 중년기에 단백질 급원으로 기대되는 식품 이라 할 수 있다(Hwang \& Choi, 2015). 일반적인 곤충의 조단백질 과 조지방 함량은 각각 50-60\%와 8.1-59\%로 고단백, 저지방 식품 으로 만성질환 개선에 도움이 되는 식품소재로 판단된다(Chong et al., 2017).

그동안 누에, 밀웜, 굼벵이는 각각 단일소재로 만성질환 관리를 위 해 활용되어왔다. 따라서 본 연구에서는 만성질환 개선을 위한 식품 소재로 곤충식품의 활용도를 높이고자 누에, 밀웜, 굼벵이의 최적 혼 합비율을 도출하여 친환경 먹거리 및 만성질환 관리를 위한 소재로서 의 가치를 규명하고자 하였다.

\section{Methods}

\section{1. 실험재료}

본 연구의 실험재료로 사용한 누에는 부안누에오디(Buanodinue, Korea), 밀웜은 (주MG네츄럴(MG Natural, Korea), 굼벵이는 봉화곤 충호텔(Bonghwa Insect Hotel, Korea)을 통하여 분말화 된 시료를 구입하여 시료로 사용하였다.

\section{2. 실험설계}

누에, 밀웜, 굼벵이의 최적 혼합비율을 도출하기 위해 반응표면 분석법(response surface methodology, RSM)의 Box-Behnken법 (Ferreira et al., 2007)에 따라 15개의 실험점을 설정하였다.

독립변수로 누에 $\left(\mathrm{X}_{1}\right)$, 밀웜 $\left(\mathrm{X}_{2}\right)$, 굼벵이 $\left(\mathrm{X}_{3}\right)$ 를 선정하였다. 각각 의 요인은 실험 결과를 바탕으로 최소 범위와 최대 범위의 값을 설정 하였고, 그 범위는 누에가 0-3 g, 밀웜은 0-3 g, 그리고, 굼벵이는 0-3 g이었다. 종속변수로는 총 BCAA 함량, 총 불포화지방산 $(\omega-3$, $\omega-6$ 및 $\omega-9)$ 함량, 총 폴리페놀 함량, 총 플라보노이드 함량, ABTS radical 소거능, $\alpha$-glucosidase 저해 활성, $\mathrm{ACE}$ 저해 활성으로 선정 하였다. 실험설계에 따른 실험점은 Table 1 에 제시된 바와 같다.

\section{3. 실험 방법}

1) 열수 추출물 제조

누에, 밀웜, 굼벵이 열수 추출물을 제조하기 위해 각각의 시료 를 $3 \mathrm{~g}$ 씩 초미세 저울로 정량한 후 $30 \mathrm{~mL}$ 의 증류수를 넣고 희석하 여 $2 \mathrm{~h}$ 동안 초음파 추출하였다. 추출한 시료는 $20 \mathrm{~min}$ 동안 원심

Table 1. Independent variables and actual values used for optimization

\begin{tabular}{|c|c|c|c|c|c|c|}
\hline \multirow{2}{*}{ No. } & \multicolumn{3}{|c|}{ Coded levels } & \multicolumn{3}{|c|}{ Actual values (ratio) } \\
\hline & $X_{1}$ & $\mathrm{X}_{2}$ & $X_{3}$ & Silkworm $\left(X_{1}\right)$ & Mealworm $\left(X_{2}\right)$ & White-grub $\left(X_{3}\right)$ \\
\hline 1 & 0 & 0 & 0 & 1.5 & 1.5 & 1.5 \\
\hline 2 & -1 & -1 & 0 & 0 & 0 & 1.5 \\
\hline 3 & -1 & 1 & 0 & 0 & 3 & 1.5 \\
\hline 4 & -1 & 0 & -1 & 0 & 1.5 & 0 \\
\hline 5 & 1 & 1 & 0 & 3 & 3 & 1.5 \\
\hline 6 & 0 & 1 & -1 & 1.5 & 3 & 0 \\
\hline 7 & 0 & 0 & 0 & 1.5 & 1.5 & 1.5 \\
\hline 8 & 1 & 0 & 1 & 3 & 1.5 & 3 \\
\hline 9 & 0 & 1 & 1 & 1.5 & 3 & 3 \\
\hline 10 & -1 & 0 & 1 & 0 & 1.5 & 3 \\
\hline 11 & 1 & 0 & -1 & 3 & 1.5 & 0 \\
\hline 12 & 1 & -1 & 0 & 3 & 0 & 1.5 \\
\hline 13 & 0 & 0 & 0 & 1.5 & 1.5 & 1.5 \\
\hline 14 & 0 & -1 & 1 & 1.5 & 0 & 3 \\
\hline 15 & 0 & -1 & -1 & 1.5 & 0 & 0 \\
\hline
\end{tabular}


분리(4,000 rpm)를 한 후 상등액을 취해 $0.45 \mu \mathrm{m}$ 의 syringe filter (Hyundai micro, Korea)로 불순물을 제거하였다. 불순물을 제거한 추출물은 20 배로 희석하여 각각의 혼합비율의 조건에 따라 혼합하여 시료로 사용하였다.

\section{2) 총 $B C A A$ 함량}

누에, 밀웜, 굼벵이의 아미노산 함량 측정 방법은 다음과 같다. 각 각의 시료 $5 \mathrm{~g}$ 과 $6 \mathrm{~N} \mathrm{HCl} 40 \mathrm{~mL}$ 를 각각 둥근 플라스크에 넣고 혼합 한 다음 $110^{\circ} \mathrm{C}$ 에서 $24 \mathrm{~h}$ 동안 질소 가스를 주입하여 가수분해 하였 다. $\mathrm{HCl}$ 를 $50^{\circ} \mathrm{C}$ 에서 감압 농축시킨 다음 농축 시료는 $0.2 \mathrm{~N}$ sodium citrate buffer (pH 2.2) (Sigma-Aldrich, USA) $50 \mathrm{~mL}$ 를 넣어 희석 시키고, $0.45 \mu \mathrm{m}$ syringe filter (Hyundai micro)로 여과하였다. 여 과한 시료 $(30 \mu \mathrm{L})$ 는 아미노산 자동분석기(AAA L-8900; Hitachi, Japan)를 사용하였고, column은 iron change column $(4.6 \mathrm{~mm} \times 60$ $\mathrm{mm}$ )을, 검출기는 visible detector를 사용하였다. 완충액의 flow rate 는 $1 \mathrm{~mL} / \mathrm{min}$, column의 온도는 $20-85^{\circ} \mathrm{C}$, 반응온도는 $50-140^{\circ} \mathrm{C}$ 로 하여 분석하였다.

\section{3) 총 불포화지방산 함량}

누에, 밀웜, 굼벵이의 지방산 조성은 Folch et al. (1957)의 방법으 로 gas chromatography (US/HP 6890, Aglient Technolgies, Santa Clara, CA, USA)를 사용하여 분석하였다. Gas chromatography (GC) 조건은 silica capillary column (Omegawax 295, $0.25 \mu \mathrm{m}$ film thickness; Sigma-Aldrich)을 이용하였고, injection port 온도 는 $250^{\circ} \mathrm{C}$, 검출기 온도는 $260^{\circ} \mathrm{C}$ 로 유지하였다.

\section{4) 총 폴리페놀 함량}

누에, 밀웜, 굼벵이의 총 폴리페놀 함량은 $\mathrm{F}-\mathrm{C}$ 시약을 사용하는 Singleton \& Rossi (1965)의 방법을 활용 및 변형하여 측정하였다. 시료 $350 \mu \mathrm{L}$ 에 50\% Folin-Ciocalte (Sigma-Aldrich) $70 \mu \mathrm{L}$ 를 가 하여 $3 \mathrm{~min}$ 간 정치, $2 \%$ (w/v) $\mathrm{Na}_{2} \mathrm{CO}_{3}$ (Sigma-Aldrich)용액 350 $\mu \mathrm{L}$ 를 첨가하여 $1 \mathrm{~h}$ 반응시킨 후, ELISA microplate reader (Tecan Infinite M200 Pro; GreenMate Bio, Korea)를 이용하여 $750 \mathrm{~nm}$ 에 서 흡광도를 측정하였다. 총 폴리페놀 함량은 tannic acid를 이용하 여 작성한 표준곡선으로부터 구하였다.

\section{5) 총 플라보노이드로 함량}

누에, 밀웜, 굼벵이의 총 플라보노이드 함량은 Davis (1947)의 방 법을 활용 및 변형하여 측정하였다. 시료 $70 \mu \mathrm{L}$ 에 diethylene glycol (Daejung, Korea) $700 \mu \mathrm{L}$ 를 첨가하였고 다시 $1 \mathrm{~N}-\mathrm{NaOH}$ (SigmaAldrich)용액 $7 \mu \mathrm{L}$ 를 첨가해서 $37^{\circ} \mathrm{C}$ (dry oven)에서 $1 \mathrm{~h}$ 반응시킨 후 ELISA microplate reader (Tecan Infinite M200 Pro, GreenMate $\mathrm{Bio})$ 를 이용하여 $420 \mathrm{~nm}$ 에서 흡광도를 측정하였다. 총 플라보노이 드 함량은 quercetin을 이용하여 작성한 표준곡선으로부터 구하였다.

\section{6) ABTS radical 소거능}

누에, 밀웜, 굼벵이의 ABTS (2,2'-azino-bis-3-ethylbenzothiazoline-6-sulfonic acid) radical 소거능은 Fellegrini et al. (1999)의 방법을 활용하여 측정하였다. ABTS (Sigma-Aldrich) 7.4 $\mathrm{mM}$ 과 potassium persulfate (Sigma-Aldrich) $2.6 \mathrm{mM}$ 을 같은 비 율로 섞어 하루 동안 암소에 방치하여 ABTS 양이온을 형성시키고 이 후 $732 \mathrm{~nm}$ 에서 흡광도 값이 $0.70 \pm 0.03$ 이 되도록 $1 \times \mathrm{PBS}$ 로 희석 하였으며, 희석된 ABTS용액 $190 \mu \mathrm{L}$ 에 시료 $10 \mu \mathrm{L}$ 를 가하여 $60 \mathrm{~min}$ 정치한 후 ELISA microplate reader (Tecan Infinite M200 Pro, GreenMate Bio)를 이용하여 $732 \mathrm{~nm}$ 에서 흡광도를 측정하였다.

\section{7) $\alpha$-Glucosidase 저해 활성}

누에, 밀웜, 굼벵이의 $\alpha$-glucosidase 억제활성은 Li et al. (2005) 의 방법을 변형하여 실험하였다. 반응 혼합물의 총 부피는 $160 \mu \mathrm{L}$ 로 통일하였다. 각각의 well에 sample $20 \mu \mathrm{L}$ 와 $100 \mathrm{mM}$ phosphate buffer (pH 6.8) (Daejung) $20 \mu \mathrm{L}$ 를 넣은 후 1 unit $/ \mathrm{mL}$ 농도로 녹 인 $\alpha$-glucosidase (10 mM phosphate buffer (pH 6.8) (Daejung) $20 \mu \mathrm{L}$ 를 넣고 $37^{\circ} \mathrm{C}$ 에서 $5 \mathrm{~min}$ 동안 pre-incubation을 시켰다. 기질 로 사용된 $2.5 \mathrm{mM} \mathrm{p}$-nitrophenyl $\alpha-\mathrm{D}$-glucopyranoside ( $p \mathrm{NPG}$; Sigma-Aldrich)는 $100 \mathrm{mM}$ phosphate buffer (pH 6.8) (Daejung) 에 녹여 $20 \mu \mathrm{L}$ 를 넣고, $37^{\circ} \mathrm{C}$ 에서 $15 \mathrm{~min}$ 동안 incubation 하였다. Incubation을 한 후 $0.2 \mathrm{M}$ sodium carbonate solution (SigmaAldrich) $80 \mu \mathrm{L}$ 를 넣어 반응을 종결한 후 microplate reader (Tecan Infinite M200 Pro, GreenMate Bio)를 이용하여 $405 \mathrm{~nm}$ 에서 흡광 도를 측정하여 $\alpha$-glucosidase 저해율을 산출하였다.

\section{8) $\mathrm{ACE}$ 저해 활성}

누에, 밀웜, 굼벵이의 $\mathrm{ACE}$ (angiotensin-converting enzyme) 저 해활성은 Cushman \& Cheung (1971)의 방법을 활용 및 변형하여 측정하였다.

기질 용액 hippury-L-histidyl-L-leucine (HHL, SigmaAldrich) $(5 \mathrm{mM})$ 은 sodium chloride를 $300 \mathrm{mM}$ 함유한 $50 \mathrm{mM} \mathrm{HCl}$ buffer ( $\mathrm{pH}$ 8.3)에 녹여서 제조한다. 효소로 사용한 ACE 용액은 기 질 제조를 할 때 이용한 것과 같은 $\mathrm{HCl}$ buffer (pH 8.3) (SigmaAldrich)에 10\% lung acetone powder rabbit (Sigma-Aldrich)을 $4^{\circ} \mathrm{C}$ 에서 overnight 한 후, 원심분리기(Combi-514R; Hanil Science Inc., Korea)에서 원심분리( $\left.12,000 \mathrm{rpm}, 30 \mathrm{~min}, 4^{\circ} \mathrm{C}\right)$ 하여 제조하 였다. ACE 저해 활성 분석은 $\mathrm{ACE}$ enzyme $50 \mu \mathrm{L}, \mathrm{HHL} 150 \mu \mathrm{L}$ 와 sample 시료 $50 \mu \mathrm{L}$ 를 혼합하였으며, 대조군 (control)은 sample 시료 대신 증류수를 $50 \mu \mathrm{L}$ 첨가하여 $37^{\circ} \mathrm{C}$ 에서 $30 \mathrm{~min}$ 간 반응시킨 후 1 $\mathrm{M} \mathrm{HCl} 250 \mu \mathrm{L}$ 를 첨가하여 반응을 중지시켰다. 여기에 ethylacetate (Sigma-Aldrich) $500 \mu \mathrm{L}$ 를 첨가하고 $15 \mathrm{~s}$ 간 교반 후 원심분리(3,000 $\mathrm{rpm}, 5 \mathrm{~min}$ ) 시켜 상등액 $200 \mu \mathrm{L}$ 를 취하였다. 상등액은 $120^{\circ} \mathrm{C}$ 에서 $30 \mathrm{~min}$ 간 완전히 건조를 시켰다. 건조물에 증류수 $1 \mathrm{~mL}$ 를 가하여 
용해를 시킨 다음 $228 \mathrm{~nm}$ 에서 흡광도를 측정하여 $\mathrm{ACE}$ 저해율을 산출하 였다.

\section{4. 통계 처리}

실험 자료의 분석과 최적혼합비율은 Design Expert 10 (Stat-Ease Inc., Minneapolis, USA) program의 ANOVA-test와 회귀분석을 이용 하였고, 모델의 적합성은 F-test로 검정하였다. 이외 모든 자료는 SPSS statistics 24 (SPSS Institute, USA) program을 이용하여 평균과 표준 편차를 구하였다. 각 요인에 대한 분석은 one-way ANOVA로 분석 후 Duncan's multiple range test로 사후 검정을 실시하였고, 유의수준은 5\% 로 설정하였다.

\section{Results and Discussion}

\section{1. 누에, 밀웜, 굼벵이 혼합물 추출시료의 총 BCAA 함량 및 총 불포화 지방산 함량}

\section{1) 총 $\mathrm{BCAA}$ 함량}

분지아미노산(branched-chain amino acid, BCAA)은 인체의 정상적인 성장발달과 근육에 에너지를 공급하여 근육 손실을 막고, 알코올성 간 손 상을 예방하는 역할을 하는 것으로 알려져 있다(Churchward-Venne et al., 2013).

누에 $\left(\mathrm{X}_{1}\right)$, 밀웜 $\left(\mathrm{X}_{2}\right)$, 굼벵이 $\left(\mathrm{X}_{3}\right)$ 의 함량을 독립변수로 하여 반응표면분 석법에 의해 설계된 15 개의 총 $\mathrm{BCAA}$ 함량을 측정하여 Table 2 에 제시하 였고, 유의성 검증 결과 및 회귀분석의 결과는 Table 3 와 Figure $1 \mathrm{~A}$ 에 제 시하였다.

누에, 밀웜, 굼벵이 혼합물 추출시료의 총 $\mathrm{BCAA}$ 의 함량을 측정한 결 과, $0.14-0.73 \mathrm{mg} / \mathrm{g}$ 의 범위를 보였고, 9 번 시료 (누에 1.5 , 밀웜 3, 굼벵 이 3)가 $0.73 \mathrm{mg} / \mathrm{g}$ 으로 가장 높았고, 15 번 시료(누에 1.5 , 밀웜 0 , 굼벵이 0)가 $0.14 \mathrm{mg} / \mathrm{g}$ 으로 가장 낮았다.

총 $\mathrm{BCAA}$ 함량은 독립변수가 독립적으로 작용하여 선형효과만 존재하 는 linear model이 선정되었다. 본 모델의 $\mathrm{R}^{2}$ 값은 0.9999 로 신뢰도가 매 우 높았고, $p$ 값이 〈0.0001로 적합성이 인정되었다. Figure $1 \mathrm{~A}$ 에 제시된 perturbation plot에 따르면 누에(A), 밀웜(B), 굼벵이(C)의 첨가 비율이 증

Table 2. Total BCAA and total unsaturated fatty acid ( $\omega-3, \omega-6$, and $\omega-9)$ contents of silkworm, mealworm, and white-grub by response surface design

\begin{tabular}{|c|c|c|c|c|c|}
\hline No. & Silkworm $\left(X_{1}\right)$ & Mealworm $\left(X_{2}\right)$ & White-grub $\left(X_{3}\right)$ & Total $\mathrm{BCAA}^{1)}(\mathrm{mg} / \mathrm{g})$ & $\begin{array}{l}\text { Total unsaturated fatty acid } \\
(\omega-3, \omega-6 \text {, and } \omega-9)(\mathrm{mg} / \mathrm{g})\end{array}$ \\
\hline 1 & 1.5 & 1.5 & 1.5 & 0.42 & 0.54 \\
\hline 2 & 0 & 0 & 1.5 & 0.16 & 0.18 \\
\hline 3 & 0 & 3 & 1.5 & 0.43 & 0.84 \\
\hline 4 & 0 & 1.5 & 0 & 0.13 & 0.33 \\
\hline 5 & 3 & 3 & 1.5 & 0.69 & 0.90 \\
\hline 6 & 1.5 & 3 & 0 & 0.40 & 0.69 \\
\hline 7 & 1.5 & 1.5 & 1.5 & 0.42 & 0.54 \\
\hline 8 & 3 & 1.5 & 3 & 0.71 & 0.75 \\
\hline 9 & 1.5 & 3 & 3 & 0.73 & 1.06 \\
\hline 10 & 0 & 1.5 & 3 & 0.46 & 0.69 \\
\hline 11 & 3 & 1.5 & 0 & 0.40 & 0.40 \\
\hline 12 & 3 & 0 & 1.5 & 0.42 & 0.24 \\
\hline 13 & 1.5 & 1.5 & 1.5 & 0.43 & 0.54 \\
\hline 14 & 1.5 & 0 & 3 & 0.45 & 0.39 \\
\hline 15 & 1.5 & 0 & 0 & 0.14 & 0.03 \\
\hline
\end{tabular}

${ }^{1)}$ BCAA, branched-chain amino acid.

Table 3. Analysis of predicted model equation for total BCAA and total unsaturated fatty acid ( $\omega-3$, $\omega-6$, and $\omega-9)$ of silkworm, mealworm and white-grub

\begin{tabular}{lccccccc}
\hline Response & Model & Mean $\pm \mathrm{SD}$ & $\mathrm{R}^{21)}$ & $F$-value & $p$-value & Lack of fit & Polynomial equation $^{2)}$ \\
\hline $\begin{array}{l}\text { Total BCAA } \\
\text { Total unsaturated fatty acid } \\
(\omega-3, \omega-6, \text { and } \omega-9)\end{array}$ & Linear & $0.42 \pm 0.17$ & 0.9999 & 59029.00 & $<0.0001$ & 0.9999 & $42.49+12.96 \mathrm{~A}+13.49 \mathrm{~B}+15.98 \mathrm{C}$ \\
\hline
\end{tabular}

${ }^{1)} 0 \leq R^{2} \leq 1$, close to indicates regression line fix the model; ${ }^{2)}$ Coded equation (the levels of the factor are coded as $+1 \sim-1$ ), $A$ : silkworm (\%); B: mealworm (\%); C: white-grub (\%). 
가할수록 총 $\mathrm{BCAA}$ 의 함량이 높았다. 그중 굼벵이(C)의 첨가 비율이 증가 할수록총 $\mathrm{BCAA}$ 의 함량이 더 많이 증가하였다.

\section{2) 총 불포화지방산 $(\omega-3, \omega-6$ 및 $\omega-9)$ 함량}

지방산 중 불포화지방산은 2 중 결합을 1 개 이상 가지고 있다. 불포 화지방산은 분자내 2중 결합의 숫자에 따라 oleic acid계(2중 결합 1개), linoleic aicd계(2중 결합 2개), linolenic acid계(2중 결합 3개), 그리고 2중 결합이 4 개 이상인 고도불포화지방산으로 나뉜다(Kweon et al., 2019). 그 중 곤충식품에 포함된 $\omega-3$ 와 $\omega-6$ 지방산은 혈중 콜레스테롤 수치를 낮 추고 심혈관을 예방에 도움을 준다고 알려져 있다(Chung et al., 2013b).

누에 $\left(\mathrm{X}_{1}\right)$, 밀웜 $\left(\mathrm{X}_{2}\right)$, 굼벵이 $\left(\mathrm{X}_{3}\right)$ 의 함량을 독립변수로 하여 반응표면 분석법에 의해 설계된 15 개의 총 불포화지방산 함량을 측정하여 Table
2 에 제시하였고, 유의성 검증 결과 및 회귀분석의 결과는 Table 3 와 Figure $1 \mathrm{~B}$ 에 제시하였다.

누에, 밀웜, 굼벵이 혼합물 추출시료의 총 불포화지방산의 함량을 측 정한 결과, $1.06-0.03 \mathrm{mg} / \mathrm{g}$ 의 범위였으며, 9 번 시료(누에 1.5 , 밀웜 3 , 굼벵이 3)가 $1.06 \mathrm{mg} / \mathrm{g}$ 으로 가장 높았고, 15 번 시료(누에 1.5 , 밀웜 0 , 굼벵이 0)가 $0.03 \mathrm{mg} / \mathrm{g}$ 으로 가장 낮았다.

총 불포화지방산의 함량은 독립변수 간에 선형효과가 있는 linear model이 선정되었다. 본 모델의 $\mathrm{R}^{2}$ 값은 0.9999 로 신뢰도가 매우 높 았고, $p$ 값이 〈0.0001로 적합성도 인정되었다. Figure $1 \mathrm{~B}$ 에 제시된 perturbation plot에 따르면 누에(A), 밀웜(B), 굼벵이(C)의 첨가 비율이 증가할수록 총 불포화지방산의 함량이 높았다. 그 중 밀웜(B)의 첨가 비 율이 증가할수록 총 불포화지방산의 함량이 더 많이 증가하였다.

Table 4. Antioxidant contents and enzyme activities of silkworm, mealworm, and white-grub by response surface design

\begin{tabular}{|c|c|c|c|c|c|c|c|c|}
\hline No. & Silkworm $\left(X_{1}\right)$ & Mealworm $\left(X_{2}\right)$ & White-grub $\left(X_{3}\right)$ & $\begin{array}{c}\text { Total } \\
\text { polyphenol } \\
\left(\mathrm{mg} \mathrm{TAE}^{1)} / \mathrm{g}\right)\end{array}$ & $\begin{array}{l}\text { Total flavonoid } \\
\left(\mathrm{mg} \mathrm{QE}^{2)} / \mathrm{g}\right)\end{array}$ & $\begin{array}{c}\text { ABTS }^{3)} \text { radical } \\
\text { scavenging } \\
\text { activity (\%) }\end{array}$ & $\begin{array}{c}\alpha \text {-Glucosidase } \\
\text { inhibitory activity } \\
(\%)\end{array}$ & $\begin{array}{c}\mathrm{ACE}^{4)} \text { inhibitory } \\
\text { activity (\%) }\end{array}$ \\
\hline 1 & 1.5 & 1.5 & 1.5 & 48.85 & 21.95 & 91.18 & 37.35 & 48.25 \\
\hline 2 & 0 & 0 & 1.5 & 43.38 & 7.20 & 89.53 & 1.31 & 5.30 \\
\hline 3 & 0 & 3 & 1.5 & 28.81 & 11.95 & 77.38 & 4.22 & 67.09 \\
\hline 4 & 0 & 1.5 & 0 & 21.19 & 12.05 & 75.00 & 6.14 & 94.82 \\
\hline 5 & 3 & 3 & 1.5 & 53.68 & 27.90 & 90.58 & 34.0 & 32.90 \\
\hline 6 & 1.5 & 3 & 0 & 42.40 & 24.50 & 87.34 & 36.79 & 93.95 \\
\hline 7 & 1.5 & 1.5 & 1.5 & 48.97 & 22.95 & 90.07 & 41.27 & 46.52 \\
\hline 8 & 3 & 1.5 & 3 & 56.95 & 25.80 & 94.20 & 45.03 & 82.00 \\
\hline 9 & 1.5 & 3 & 3 & 43.81 & 20.55 & 88.01 & 27.79 & 55.04 \\
\hline 10 & 0 & 1.5 & 3 & 39.49 & 10.05 & 84.14 & 2.03 & 60.63 \\
\hline 11 & 3 & 1.5 & 0 & 63.94 & 41.65 & 95.49 & 60.48 & 67.09 \\
\hline 12 & 3 & 0 & 1.5 & 76.25 & 38.55 & 99.60 & 54.68 & 69.04 \\
\hline 13 & 1.5 & 1.5 & 1.5 & 48.72 & 23.95 & 90.66 & 37.42 & 50.13 \\
\hline 14 & 1.5 & 0 & 3 & 63.46 & 23.37 & 95.29 & 25.82 & 74.47 \\
\hline 15 & 1.5 & 0 & 0 & 78.30 & 43.00 & 99.31 & 68.09 & 59.16 \\
\hline
\end{tabular}

${ }^{11} \mathrm{TAE}$, tannic acid equivalent; ${ }^{2)} \mathrm{QE}$, quercetin acid equivalent; ${ }^{3)} \mathrm{ABTS}, 2,2$-azino-bis-3-ethylbenzo-thiazoline-6-sulfonic acid picrylhydrazyl; ${ }^{4)} \mathrm{ACE}$, angiotensinconverting enzyme.

Table 5. Analysis of predicted model equation for antioxidant contents and enzymatic activities of silkworm, mealworm, and white-grub

\begin{tabular}{|c|c|c|c|c|c|c|c|}
\hline Response & Model & Mean $\pm S D$ & $\mathrm{R}^{21)}$ & $F$-value & $p$-value & Lack of fit & Polynomial equation ${ }^{2)}$ \\
\hline Total polyphenol & Quadratic & $50.55 \pm 4.54$ & 0.9583 & 22.98 & 0.0003 & 0.0005 & $\begin{array}{c}49.77+14.74 A-11.58 B-0.26 A C+4.06 B C- \\
5.07 \times A^{2}+6.53 \times B^{2}\end{array}$ \\
\hline Total flavonoid & Linear & $23.69 \pm 5.26$ & 0.8196 & 16.66 & 0.0003 & 0.0229 & $23.69+11.58 \mathrm{~A}-3.40 \mathrm{~B}-5.18 \mathrm{C}$ \\
\hline $\begin{array}{l}\text { ABTS radical scavenging } \\
\text { ability }\end{array}$ & Quadratic & $89.85 \pm 1.98$ & 0.9542 & 27.79 & 0.1143 & 0.0577 & $\begin{array}{c}90.57+6.73 A-5.05 B+0.56 C-2.61 A C- \\
3.31 \times A^{2}+1.97 \times B^{2}\end{array}$ \\
\hline $\begin{array}{l}\alpha \text {-Glucosidase } \\
\text { inhibitory activity }\end{array}$ & Quadratic & $32.16 \pm 5.96$ & 0.9718 & 19.16 & 0.0023 & 0.0837 & $\begin{array}{c}38.68+22.56 \mathrm{~A}-5.89 \mathrm{~B}-8.85 \mathrm{C}- \\
5.90 \mathrm{AB}-2.84 \mathrm{AC}+8.32 \mathrm{BC}-13.17 \times \mathrm{A}^{2}- \\
1.96 \times \mathrm{B}^{2}+2.91 \times \mathrm{C}^{2}\end{array}$ \\
\hline ACE inhibitory activity & Quadratic & $60.43 \pm 6.34$ & 0.9620 & 25.32 & 0.0002 & 0.0569 & $\begin{array}{c}45.60+2.90 A+5.13 B-5.36 C- \\
24.48 A B+12.28 A C-13.56 B C+27.79 \times C^{2}\end{array}$ \\
\hline
\end{tabular}

${ }^{1)} 0 \leq R^{2} \leq 1$, close to indicates regression line fix the model; ${ }^{2)}$ Coded equation (the levels of the factor are coded as $+1 \sim-1$ ), $A:$ silkworm (\%), B: mealworm (\%), C: white-grub (\%). 
A

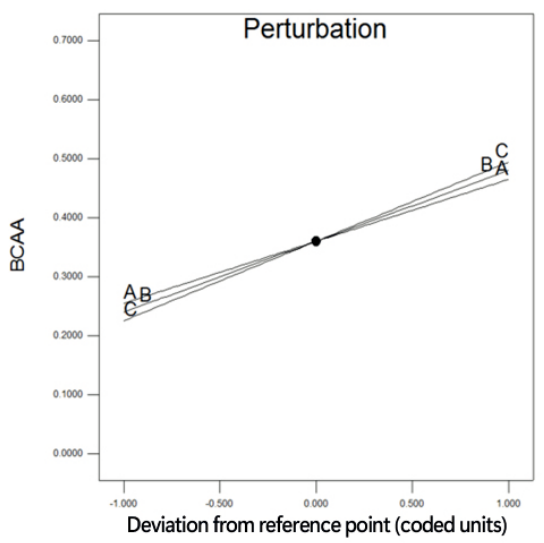

C

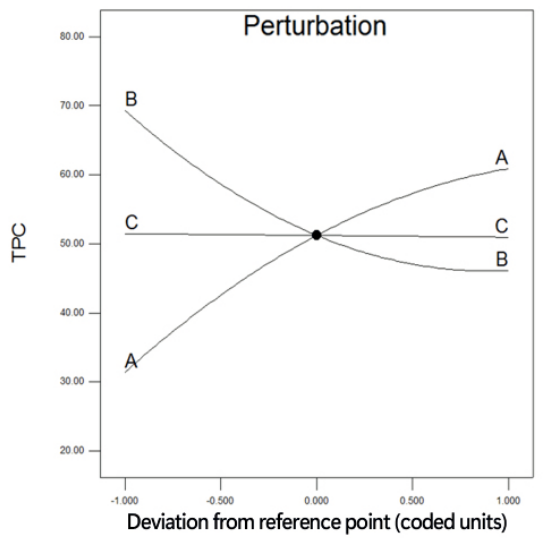

$E$

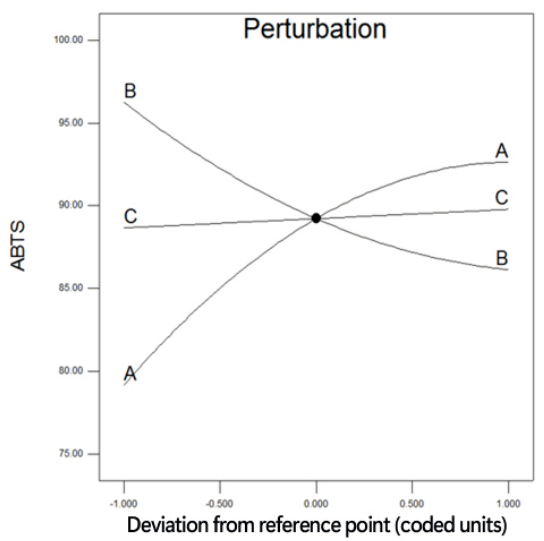

G

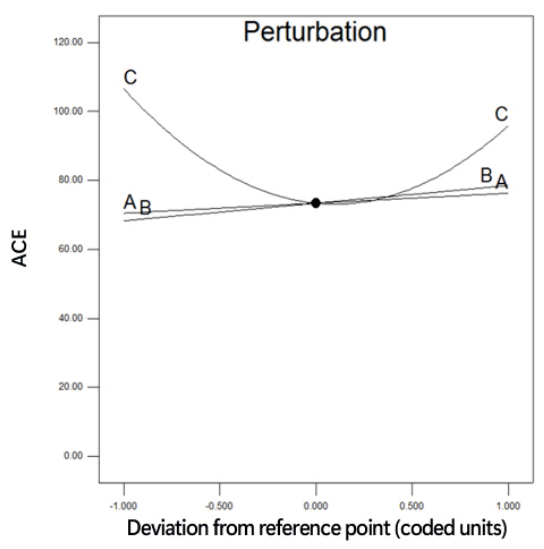

B

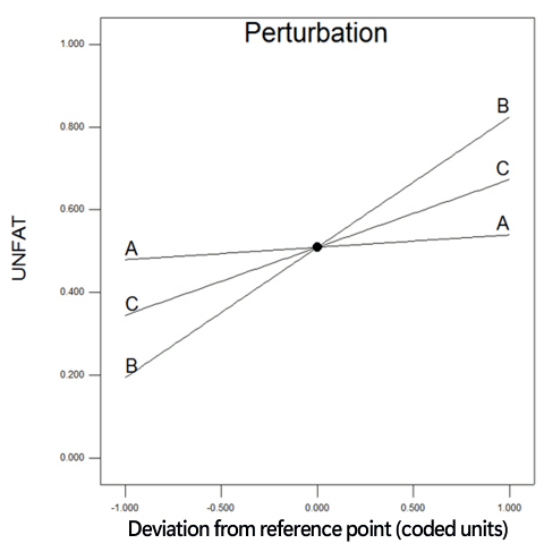

D

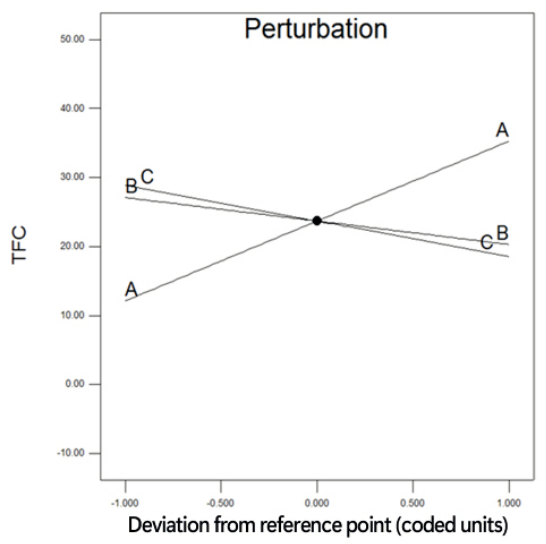

$\mathbf{F}$

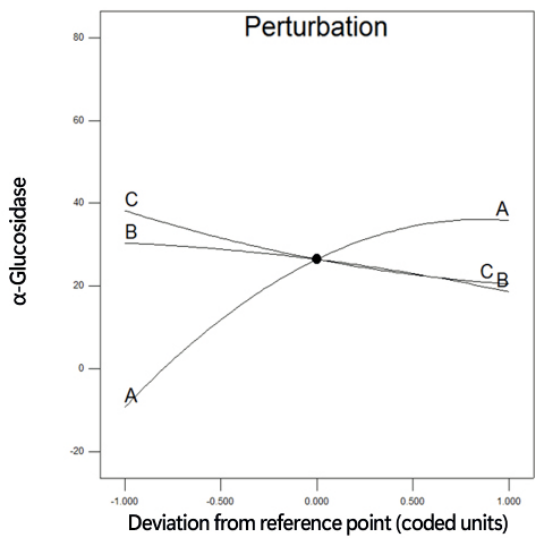

Figure 1. Perturbation plot of silkworm (A), mealworm (B) and white-grub (C).

(A) Total BCAA contents; (B) Total unsaturated fatty acid contents; (C) Total polyphenol content); (D) Total flavonoid content; (E) ABTS radical scavenging activity; (F) $\alpha$-glucosidase inhibitory activity; (G) ACE inhibitory activity. BCAA, branched-chain amino acid; UNFAT, unsaturated fatty acid; ABTS, 2,2'-azino-bis-3ethylbenzo-thiazoline-6-sulfonic acid picrylhydrazyl; TFA, total flavonoid; TPA, total polyphenol; ACE, angiotensin-converting enzyme. 


\section{2. 누에, 밀웜, 굼벵이 혼합물 추출시료의 생리활성 지표}

\section{1) 총 폴리페놀 함량}

식물의 항산화 성분인 폴리페놀은 체내의 활성산소를 자유 라디 칼로 안정시켜 산화 스트레스로 인한 손상을 예방하는 효과가 있다 (Jung et al., 2019).

누에 $\left(\mathrm{X}_{1}\right)$, 밀웜 $\left(\mathrm{X}_{2}\right)$, 굼벵이 $\left(\mathrm{X}_{3}\right)$ 의 함량을 독립변수로 하여 반응표 면분석법에 의해 설계된 15 개의 총 폴리페놀 함량을 측정하여 Table 4에 제시하였고, 유의성 검증 결과 및 회귀분석의 결과는 Table 5 와 Figure $1 \mathrm{C}$ 에 제시하였다.

누에, 밀웜, 굼벵이 혼합물 추출시료의 총 폴리페놀의 함량을 측 정한 결과, $21.19-78.30 \mathrm{mg} \mathrm{TAE} / \mathrm{g}$ 의 범위였으며, 15 번 시료(누에 1.5 , 밀웜 0 , 굼벵이 0)가 $78.30 \mathrm{mg} / \mathrm{g}$ 으로 가장 높았고, 4 번 시료(누 에 0, 밀웜 1.5, 굼벵이 0)가 $21.19 \mathrm{mg} \mathrm{TAE} / \mathrm{g}$ 으로 가장 낮았다.

총 폴리페놀의 함량은 독립변수 간에 선형효과와 곡선효과가 함께 나타나는 quadratic model이 선정되었다. 본 모델의 $\mathrm{R}^{2}$ 값은 0.9583 으로 신뢰도가 매우 높았고, $p$ 값이 $0.0003(p<0.001)$ 로 적합성도 인 정되었다. Figure $1 \mathrm{C}$ 에 제시된 perturbation plot에 따르면 누에(A) 의 첨가 비율이 높을수록 총 폴리페놀의 함량이 높았고, 밀웜(B)의 첨가 비율이 증가할수록 총 폴리페놀의 함량은 감소하였다.

\section{2) 총 플라보노이드 함량}

플라보노이드(flavonoid)는 활성산소종을 효과적으로 제거하여 항 산화능이 높고, 항바이러스, 항염증 등에 효과적인 것으로 알려져 있 다(Kim et al., 2012).

누에 $\left(\mathrm{X}_{1}\right)$, 밀웜 $\left(\mathrm{X}_{2}\right)$, 굼벵이 $\left(\mathrm{X}_{3}\right)$ 의 함량을 독립변수로 하여 반응표 면분석법에 의해 설계된 15 개의 총 플라보노이드의 함량을 측정하 여 Table 4 에 제시하였고, 유의성 검증 결과 및 회귀분석의 결과는 Table 5 와 Figure $1 \mathrm{D}$ 에 제시하였다.

누에, 밀웜, 굼벵이 혼합물 추출시료의 총 플라보노이드의 함량을 측정한 결과, $7.20-43.00 \mathrm{mg} \mathrm{QE} / \mathrm{g}$ 의 범위였으며, 15 번 시료(누에 1.5 , 밀웜 0 , 굼벵이 0)가 $43.00 \mathrm{mg} \mathrm{QE} / \mathrm{g}$ 으로 가장 높았고, 2 번 시 료(누에 0, 밀웜 0 , 굼벵이 1.5 )가 $7.20 \mathrm{mg} \mathrm{QE} / \mathrm{g}$ 으로 가장 낮았다.

총 플라보노이드의 함량은 독립변수 간에 선형효과가 있는 linear model이 선정되었다. 본 모델의 $\mathrm{R}^{2}$ 값은 0.8196 으로 신뢰도가 높고, $p$ 값이 $0.0003(p<0.001)$ 로 적합성도 인정되었다. Figure $1 \mathrm{D}$ 에 제시 된 perturbation plot에 따르면 누에(A)의 첨가 비율이 높을수록 총 폴리페놀의 함량이 높았고, 밀웜 $(\mathrm{B})$ 과 굼벵이(C)의 첨가 비율이 증가 할수록 총 폴리페놀의 함량은 감소하였다.

\section{3) ABTS radical 소거능}

$\mathrm{ABTS}$ radical 소거능의 측정방법은 $\mathrm{DPPH}$ assay와 마찬가지로 인 위적으로 radical을 제거하는 작용으로 $\mathrm{DPPH}$ radical 소거능과 유의 한 상관성을 보이는 것으로 알려져 있는데(Park et al., 2014), 친수 성 및 소수성 화합물의 항산화력 측정이 가능한 ABTS radical 소거능
은 $734 \mathrm{~nm}$ 파장에서 최대한의 흡광도를 가지며, 추출물 색소에 의한 영향이 최소한으로 작용하므로 $\mathrm{DPPH}$ 보다 정확한 항산화력을 측정 할 수 있다(Boligon et al., 2014). ABTS radical 소거능은 potassium persulfate와의 반응으로 인해 생성된 ABTS 유리 라디칼이 추출물 내의 항산화 물질에 의해 제거되어 라디칼 특유의 색인 청록색이 탈 색되는 것을 이용하여 측정하는 방법이다(Lee \& Ryu, 2019).

누에 $\left(\mathrm{X}_{1}\right)$, 밀웜 $\left(\mathrm{X}_{2}\right)$, 굼벵이 $\left(\mathrm{X}_{3}\right)$ 의 함량을 독립변수로 하여 반응 표면분석법에 의해 설계된 15 개의 $\mathrm{ABTS}$ radical 소거능을 측정하 여 Table 4 에 제시하였고, 유의성 검증 결과 및 회귀분석의 결과는 Table 5 와 Figure $1 \mathrm{E}$ 에 제시하였다.

누에, 밀웜, 굼벵이 혼합물 추출시료의 ABTS radical 소거능을 측 정한 결과, 84.14-99.60 mg QE/g의 범위였으며, 12 번 시료(누에 3, 밀웜 0, 굼벵이 1.5)가 $99.60 \%$ 로 가장 높았고, 10 번 시료(누에 0, 밀 웜 3, 굼벵이 1.5$)$ 가 $84.14 \%$ 로 가장 낮았다.

ABTS radical 소거능은 독립변수 간에 선형효과와 곡선효과가 함께 나타나는 quadratic model이 선정되었다. 본 모델의 R2 값은 0.9542 로 신뢰도가 높았고, $p$ 값이 0.1143 ( $p<0.001$ )로 적합성도 인 정되었다. Figure 1E에 제시된 perturbation plot에 따르면 누에(A) 와 굼벵이(C)의 첨가 비율이 높을수록 $\mathrm{ABTS}$ radical 소거능의 효과 가 높았고, 밀웜(B)의 첨가 비율이 증가할수록 ABTS radical 소거능 의 효과는 상대적으로 감소하였다.

\section{4) $\alpha$-Glucosidase 저해 활성}

$\alpha$-Glucosidase는 소장 내의 탄수화물로부터 $\alpha$-glucosidase를 방 출하는 $\alpha$-glucosidase bond의 분해를 촉진하여 포도당을 흡수하는 데 관여하는 필수 효소이다(Kim et al., 2015).

누에 $\left(\mathrm{X}_{1}\right)$, 밀웜 $\left(\mathrm{X}_{2}\right)$, 굼벵이 $\left(\mathrm{X}_{3}\right)$ 의 함량을 독립변수로 하여 반응표 면분석법에 의해 설계된 15 개의 $\alpha$-glucosidase 저해 활성을 측정하 여 Table 4 에 제시하였고, 유의성 검증 결과 및 회귀분석의 결과는 Table 5 와 Figure 1F에 제시하였다.

누에, 밀웜, 굼벵이 혼합물 추출시료의 $\alpha$-glucosidase 저해 활성 을 측정한 결과, 1.31-68.09\%의 범위였으며, 15 번 시료(누에 1.5 , 밀웜 0, 굼벵이 1.5 )가 $68.09 \%$ 로 가장 높았고, 2 번 시료(누에 0 , 밀 웜, 굼벵이 1.5 )가 $1.31 \%$ 로 가장 낮았다.

$\alpha$-Glucosidase 저해 활성은 독립변수 간에 선형효과와 곡선효과 가 함께 나타나는 quadratic model이 선정되었다. 본 모델의 $\mathrm{R}^{2}$ 값은 0.9718 로 신뢰도가 높고, $p$ 값이 $0.0023(p<0.001)$ 로 적합성도 인정 되었다. Figure $1 \mathrm{~F}$ 에 제시된 perturbation plot에 따르면 누에(A)의 첨가 비율이 증가할수록 $\alpha$-glucosidase 저해 활성이 높게 나타나 누 에는 당뇨병 관리에 도움이 되는 소재로 판단된다.

\section{5) $\mathrm{ACE}$ 저해 활성}

$\mathrm{ACE}$ 는 항고혈압 효과의 효소 인자로 angiotensin I로부터 $\mathrm{C}$-말 단 dipeptide를 가수분해 시켜서 강력한 혈관 수축작용을 나타내는 


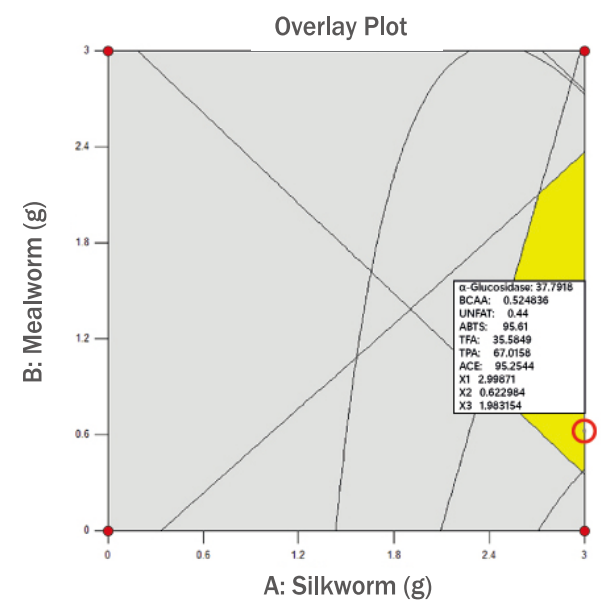

Figure 2. Derived total BCAA contents, total unsaturated fatty acid $(\omega-3, \omega-6, \omega-9)$ contents, antioxidant, and enzymatic activities optimal blend ratio.

BCAA, branched-chain amino acid; UNFAT, unsaturated fatty acid; ABTS, 2,2'-azino-bis-3-ethylbenzo-thiazoline-6-sulfonic acid picrylhydrazyl; TFA, total flavonoid; TPA, total polyphenol; ACE, angiotensin-converting enzyme.

angiotensin II를 생성하여 고혈압의 원인이 되고 있다(Jang et al., 2010). Angiotensin II 는 혈압을 상승시키는 작용을 하며 $\mathrm{ACE}$ 의 작 용이 계속 지속하면, 고혈압을 유발하여 혈관 벽이 얇아져 터지게 되 거나, 뇌졸중 등의 여러 질환이 발생한다(Fujita et al., 2000).

누에 $\left(\mathrm{X}_{1}\right)$, 밀웜 $\left(\mathrm{X}_{2}\right)$, 굼벵이 $\left(\mathrm{X}_{3}\right)$ 의 함량을 독립변수로 하여 반응 표면분석법에 의해 설계된 15 개의 $\mathrm{ACE}$ 저해 활성을 측정하여 Table 4에 제시하였고, 유의성 검증 결과 및 회귀분석의 결과는 Table 5 와 Figure $1 \mathrm{G}$ 에 제시하였다.

누에, 밀웜, 굼벵이 혼합물 추출시료의 $\mathrm{ACE}$ 저해 활성을 측정한 결과, 5.30-94.82\%의 범위였으며, 4 번 시료(누에 0, 밀웜 1.5, 굼 벵이 0)가 $94.82 \%$ 로 가장 높았고, 2 번 시료(누에 0 , 밀웜 0 , 굼벵이 1.5)가 5.30\%로 가장 낮았다.

$\mathrm{ACE}$ 저해 활성 저해 활성은 독립변수 간에 선형효과와 곡선효과 가 함께 나타나는 quadratic model이 선정되었다. 본 모델의 $\mathrm{R}^{2}$ 값은 0.9620 로 신뢰도가 높고, $p$ 값이 0.0002 ( $p<0.001$ )로 나타나 적합성 도 인정되었다. Figure $1 \mathrm{G}$ 에 제시된 perturbation plot에 따르면 누 에(A)와 밀웜(B)의 첨가 비율이 증가할수록 $\mathrm{ACE}$ 저해 활성이 높게 나타나 누에와 밀웜이 고혈압 관리 소재로의 가능성이 있는 것으로 판단된다.

\section{3. 반응표면분석을 이용한 누에, 밀웜, 굼벵이 혼합비율 최적화}

최적의 desirability를 나타낸 최적혼합비율의 산출 결과는 Figure 2 에 제시된 바와 같다. 반응표면분석에 의해 도출된 최적혼합비율은 누에 $\left(\mathrm{X}_{1}\right)$ 2.998:밀웜 $\left(\mathrm{X}_{2}\right)$ 0.623:굼벵이 $\left(\mathrm{X}_{3}\right)$ 1.983으로 나타났다. 최
적혼합비율의 총 $\mathrm{BCAA}$ 함량은 $0.52 \mathrm{~g}$, 총 불포화지방산 함량은 0.44 $\mathrm{g}$, 총 폴리페놀 함량은 $67.02 \mathrm{mg} \mathrm{TAE} / \mathrm{g}$, 총 플라보노이드 함량은 $35.58 \mathrm{mg} \mathrm{QE} / \mathrm{g}$, ABTS radical 소거능은 95.61\%, $\alpha$-glucosidase 저해 활성은 $37.79 \%, \mathrm{ACE}$ 저해 활성은 $95.25 \%$ 로 나타났다. 누에, 밀웜, 굼벵이 최적 혼합비율에 해당하는 종속변수 중 항산화 활성과 $\mathrm{ACE}$ 저해 활성효과가 높게 나타나 당뇨병 합병증과 간장질환 개선 에 도움이 될 것으로 보여진다.

\section{Conclusion}

그동안 누에, 밀웜, 굼벵이는 각각 단일소재로 당뇨병이나 간장 질환과 같은 만성질환 관리를 위해 활용되어왔다. 따라서 본 연구에 서는 만성질환 개선을 위한 식품소재로 곤충식품의 활용도를 높이 고자 독립변수로 누에, 밀웜, 굼벵이를, 종속변수로는 총 $\mathrm{BCAA}$ 함 량, 총 불포화지방산 함량, 총 폴리페놀 함량, 총 플라보노이드 함량, $\mathrm{ABTS}$ radical 소거능, $\alpha$-glucosidase 저해 활성, $\mathrm{ACE}$ 저해 활성을 선정하여 누에, 밀웜, 굼벵이의 최적혼합비율을 도출하고자 하였다. 그 결과 누에, 밀웜, 굼벵이의 최적혼합비율은 누에 $\left(\mathrm{X}_{1}\right) 2.998$ : 밀웜 $\left(\mathrm{X}_{2}\right) 0.623$ : 굼벵이 $\left(\mathrm{X}_{3}\right) 1.983$ 으로 도출되었다. 최적비율의 누에, 밀 웜, 굼벵이 혼합물에 포함된 총 $\mathrm{BCAA}$ 함량은 $0.52 \mathrm{~g}$, 총 불포화지 방산 함량은 $0.44 \mathrm{~g}$, 총 폴리페놀 함량은 $67.02 \mathrm{mg} \mathrm{TAE} / \mathrm{g}$, 총 플라 보노이드 함량은 $35.58 \mathrm{mg} \mathrm{QE} / \mathrm{g}$, ABTS radical 소거능은 $95.61 \%$, $\alpha$-glucosidase 저해 활성은 $37.79 \%, \mathrm{ACE}$ 저해 활성은 $95.25 \%$ 로 나 타나 항산화 활성과 고혈압 개선에 도움이 될 것으로 기대된다.

본 연구를 통해 도출된 누에, 밀웜, 굼벵이의 최적혼합물은 단백질 대체식품으로의 활용과 더불어 만성질환을 관리하기 위한 기능성 식 품 개발 시 활용되기를 기대한다.

\section{Author's contribution}

K.A.J. designed all experimental design. L.S.Y. and H.M.R. collected literature and contributed to all aspects of analysis and experiment. L.S.Y. and H.M.R. wrote the manuscript with assistance from K.A.J.

\section{Author details}

So-Young Lee (Adjunct Professor), Department of Medium Therapy, Graduate School of Alternative Medicine, Kyonggi University, 24, Kyonggidae-ro, 9-gil, Seodaemungu, Seoul 03746, Korea; Myung-Ryun Han (Professor), Department of Baking Science \& Technology, Hyejeon College, 25, Daehak-gil, Hongseong-eup, Hongseonggun, Chungcheongnam-do 32244, Korea; Ae-Jung Kim (Professor), Department of Nutrition Therapy, Graduate 
School of Alternative Medicine, Kyonggi University, 24, Kyonggidae-ro, 9-gil, Seodaemun-gu, Seoul 03746, Korea.

\section{References}

Arsenault JE, Brown KH. Effects of protein or amino-acid supplementation on the physical growth of young children in low-income countries. Nutrition Reviews, 75: 699-717, 2017.

Baek M, Hwang JS, Kim MA, Kim SH, Goo TW, Yun EY. Comparative analysis of nutritional components of edible insects registered as novel foods. Journal of Life Science, 27: 334-338, 2017.

Bogueva D, Marinova D, Raphaely T, Schmidinger K. Environmental, health, and business opportunities in the new meat alternatives market. IGI Glpbal, Pennsylvania, pp166-181, 2019.

Boligon AA, Machado MM, Athayde ML. Technical evaluation of antioxidant activity. Medicinal Chemistry, 4: 517-522, 2014.

Bovera F, Piccolo G, Gasco L, Marono S, Loponte R, Vassalotti G. Yellow mealworm larvae (Tenebrio molitor, L.) as a possible alternative to soybean meal in broiler diets. British Poultry Science, 56: 569-575, 2015.

Choi HS, Kim SA, Shin HJ. Present and perspective on insect biotechnology. Korean Society for Biotechnology and Bioengineering Journal, 30: 257-267, 2015.

Chong HS, Kim SY, Cho SR, Park HI, Baek JE, Kuk JS, Suh HJ. Characteristics of quality and antioxidant activation of the cookies adding with mealworm (Tenebrio molitor) and black bean powder. Journal of Food Hygiene and Safety, 32: 521-530, 2017.

Cushman DW, Cheung HS. Spectrophotometric assay and properties of the angiotensin-converting enzyme of rabbit lung. Biochemical Pharmacology, 20: 1637-1648, 1971.

Chung MY, Kwon EY, Hwang JS, Goo TW, Yun EY. Pre-treatment conditions on the powder of Tenebrio molitor for using as a novel food ingredient. Journal of Sericulture Entomological Science, 51: 9-14, 2013a.

Chung MY, Hwang JS, Goo TW, Yun EY. Analysis of general composition and harmful material of protaetia brevitarsis. Journal of Life Science, 23: 664-668, 2013b.

Churchward-Venne TA, Murphy $\mathrm{CH}$, Longland TM, Phillips SM.
Role of protein and amino acids in promoting lean mass accretion with resistance exercise and attenuating lean mass loss during energy deficit in humans. Amino Acids, 45: 231-240, 2013.

Davis WB. Determination of flavanones in citrus fruits. Analytical Chemistry, 19: 476-478, 1947.

Evans JD, Flore R, Frøst MB. On eating insects: essays, stories and recipes. Phaidon, New York, pp55-58, 2017.

Fellegrini N, Ke R, Yang M, Rice-Evans C. Screening of dietary carotenoids and carotenoid-rich fruit extracts for antioxidant activities applying 2,2'-azinobis (3-ethylenebenzothiazoline-6-sulfonic acid) radical cation decolorization assay. Methods in Enzymology, 299: 379389, 1999.

Ferreira SLC, Bruns RE, Ferreira HS, Matos GD, David JM, Brandão GC, da Silva EGP, Portugal LA, dos Reis PS, Souza AS, dos Santos WNL. Box-Behnken design: an alternative for the optimization of analytical methods. Science Direct, 597: 179-186, 2007.

Folch J, Lees M, Sloane-Stanley GH. A simple method for the isolation and purification of total lipid from animal tissues. Journal of Biological Chemistry, 226: 497-502, 1957.

Fujita H, Yokoyama K, Yoshikawa M. Classification and antihypertensive activity of angiotensin I -converting enzyme inhibitory peptides derived from food proteins. Journal of Food Science, 65: 564-569, 2000.

Hwang SY, Bae G, Choi SK. Preferences and purchase intention of Tenebrio molitor (mealworm) according to cooking method. Culinary Science and Hospitality Research, 21: 100-115, 2015.

Hwang SY, Choi SK. Quality characteristics of muffins containing mealworm (Tenebrio molitor). Culinary Science \& Hospitality Research, 21: 104-115, 2015.

Jang YK, Kwon JS, Jo YW, Kim GM, Kim HK. Clinical nutrition. Shinkwang Publisher, Seoul, p152, 2010.

Jung YH, Han JS, Kim AJ. Quality evaluation and antioxidant activity of inner beauty tea prepared from roasted lotus root and burdock. Asian Journal of Beauty and Cosmetology, 17: 235-245, 2019.

Kim EJ, Choi JY, Yu MR, Kim MY, Lee SH, Lee BH. Total polyphenols, total flavonoid contents, and antioxidant activity of Korean natural and medicinal plants. Korean Journal of Food Science and Technology, 44: 337-342, 2012. 
Kim MJ, Im KR, Yoon KS. Effect of medicinal herb prepared through traditional antidiabetic prescription on $\alpha$-glucosidase activity and evaluation method for antimelanogenesis agents using $\alpha$-glucosidase activity. Journal of the Korean Society of Food Science and Nutrition, 44: 993-999, 2015.

Kim SY, Kwak KW, Lee KY, Ko HJ, Kim YS, Kim E, Park K, Yoon HJ. Comparative analysis of nutritional components of Zophobas atratus Larvae raised with artificial diet and wheat bran. Journal of Life Science, 30: 1109-1117, 2020.

Kweon HY, Jo YY, Kim H, Ju WT, Lee JH. Proximate and nutritional compositions of freeze-dried silkworm powder as edible insect resources. Journal of Sericultural and Entomological Science, 55: 33-39, 2019.

Lee AY, Lee J, Kim HS, Choi G. Inorganic components of insect origin medicines. Korean Herbal Medicine Informatics, 7: 189-194, 2019.

Lee YS, Ryu MJ. Antioxidant effects of Cinnamomum cassia bark extract and its effectiveness as a cosmetics ingredient. Asian Journal of Beauty and Cosmetology, 17: 69-80, 2019.

Li T, Zhang X, Song Y, Liu J. A microplate-based screening method for $\alpha$-glucosidase inhibitors. Chinese Journal of Clinical Pharmacology and Therapeutics, 10: 1129-1131, 2005.
Seo EJ, Ryu SD. Delicious bugs: future food, food insect story. Rejam, Seoul, pp39-96, 2019.

Singleton VL, Rossi JA. Colorimetry of total phenolics with phosphomolybdic-phosphotungstic acid reagents. American Journal of Enology and Viticulture, 16: 144-158, 1965.

Park $\mathrm{CH}$, Kim KH, Yook HS. Comparison of antioxidant and antimicrobial activities in Siraegi (dried radish greens) according to cooking process. The Korean Journal of Food and Nutrition, 27: 609-618, 2014.

Pihlanto-Leppälä A. Bioactive peptides derived from bovine whey proteins: opioid and ACE-inhibitory peptides. Trends in Food Science \& Technology, 11: 347-356, 2000.

Youn K, Kim JY, Yeo H, Yun EY, Hwang JS, Jun M. Fatty acid and vola-tile oil compositions of Allomyrina dichotoma larvae. Preventive Nutrition and Food Science, 17: 310-314, 2012.

Yu JS, Woo KS, Hwang IG, Lee YR, Kang TS, Jeong HS. ACE inhibitory and antioxidative activities of silkworm larvae (Bombyx mori) hydrolysate. Journal of the Korean Society of Food Science and Nutrition, 37: 136-140, 2008.

Van Huis A, Itterbeeck JV, Klunder H, Mertens E, Halloran A, Muir G, Vantomme P. Edible insects: future prospects for food and feed security. Food and Agri-culture Organization of the United Nations, Rome, pp7-21, 2013. 


\section{국문초록}

\section{반응표면분석법을 이용한 누에, 밀웜 및 굼벵이의 혼합비율 최적화}

이소영 ${ }^{1}$, 한명륜 ${ }^{2}$, 김애정 ${ }^{3 *}$

${ }^{1}$ 경기대학교 대체의학대학원 매체테라피전공, 서울, 한국

${ }^{2}$ 혜전대학교 제과제빵학과, 충청남도 홍성군, 한국

${ }^{3}$ 경기대학교 대체의학대학원 식품치료전공, 서울, 한국

목적: 본 연구에서는 만성질환 개선을 위한 식품소재로 곤충식품의 활용도를 높이고자 반응표면분석을 이용하여 누에, 밀웜, 굼벵 이의 최적혼합비율을 도출하고자 하였다. 방법: 독립변수로 누에, 밀웜, 굼벵이를, 종속변수로는 총 BCAA 함량, 총 불포화지방산 함량, 총 폴리페놀 함량, 총 플라보노이드 함량, ABTS radical 소거능, $\alpha$-glucosidase 저해 활성, ACE 저해 활성으로 선정하여 누에, 밀웜, 굼벵이의 최적혼합비율을 구하였다. 결과: 반응표면분석을 통해 도출된 누에, 밀웜, 굼벵이의 최적혼합비율은 누에 $\left(\mathrm{X}_{1}\right) 2.998$ : 밀웜 $\left(\mathrm{X}_{2}\right) 0.623$ : 굼벵이 $\left(\mathrm{X}_{3}\right) 1.983$ 이었다. 이때의 총 $\mathrm{BCAA}$ 함량은 $0.52 \mathrm{~g}$, 총 불포화지방산 함량은 $0.44 \mathrm{~g}$, 총 폴리페놀 함량은 $67.02 \mathrm{mg} \mathrm{TAE} / \mathrm{g}$, 총 플라보노이드 함량은 $35.58 \mathrm{mg} \mathrm{QE} / \mathrm{g}$, ABTS radical 소거능은 $95.61 \%$, $\alpha$-glucosidase 저해 활성은 $37.79 \%$, $\mathrm{ACE}$ 저해 활성은 $95.25 \%$ 로 나타났다. 결론: 본 연구를 통해 도출된 누에, 밀웜, 굼벵이의 최적혼합물이 만성질환 개선을 위한 제품 개발의 소재로 활용되기를 기대한다.

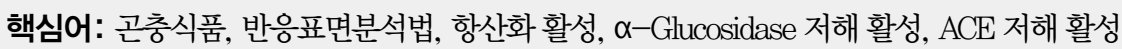

\section{참고문헌}

백민희, 황재삼, 김미애, 김수희, 구태원, 윤은영. 새로운 식품원료로 등록된 식용곤충의 영양성분 비교 분석. 한국생명과 학회지, 27: 334-338, 2017.

최환석, 김선암, 신현재. 곤충생물공학의 현재와 전망. 한국생물공학회지, 30: 257-267, 2015.

정희선, 김수연, 조성륜, 박현일, 백지은, 국지수, 서희재. 식용 밀웜(Tenebrio molitor)분말과 검은콩 분말을 첨가한 쿠키 의 품질특성 및 항산화 활성. 한국식품위생안정성학회지, 32: 521-530, 2017.

정미연, 권은영, 황재삼, 구태원, 윤은영. 갈색거저리의 식품 원료화를 위한 분말제조 조건 확립. 한국잠사학회지, $51:$ 9-14, 2013a.

정미연, 권은영, 황재삼, 구태원, 윤은영. 흰점박이꽃무지(Protaetia brevitarsis)의 일반성분 및 유해물질 분석. 한국생명 과학회지, 23: 664-668, 2013b.

황수영, 배금광, 최수근. 갈색거저리(밀웜)의 조리방법에 따른 기호도 및 구매의도에 관한 연구. 한국조리학회지, 21 : 100-115, 2015.

황수영, 최수근. 밀웜(갈색거저리) 분말 첨가 머핀의 품질 특성. 한국조리학회지, 21: 104-115, 2015.

장유경, 권종숙, 조여원, 김경민, 김혜경. 임상영양학. 신광출판사, 서울, $\mathrm{p} 152,2010$.

정연희, 한정순, 김애정. 로스팅한 연근과 우엉을 이용한 이너 뷰티 차의 항산화 활성과 품질 평가. 아시안뷰티화장품학술

지, 17: 235-245, 2019.

김은진, 최주연, 유미리, 김미영, 이상현, 이복희. 자생식물과 생약자원 추출물의 폴리페놀, 플라보노이드 함량 및 항산화

활성 탐색. 한국식품과학회지, 44: 337-342, 2012.

김미진, 임경란, 윤경섭. 당뇨 처방에 근거한 생약재의 $\alpha$-glucosidase 활성 저해 효과 및 이를 활용한 미백 소재 평가법. 한국식품영양과학회지, 44: 993-999, 2015.

김선영, 곽규원, 이경용, 고현진, 김용순, 김은선, 박관호, 윤형주. 인공사료와 밀기울로 사육한 아메리카왕거저리 유충의 
영양성분 비교분석. 한국생명과학회지, 30: 1109-1117, 2020.

권해용, 조유영, 김현복, 주완택, 이지혜. 동결건조 누에분말의 일반 성분 및 영양 성분. 한국잠사학회지, 55: 33-39, 2019

이아영, 이준, 김효선, 최고야. 곤충기원 한약재의 무기성분 함량. 한약정보연구회지, 7: 189-194, 2019.

이영숙, 유민정. 계피 추출물의 항산화 효과 및 화장품소재의 응용. 아시안뷰티화장품학술지, 17: 69-80, 2019. 류정표. 세계 식용곤충 시장 및 가공기술 동향. 세계농업, 207: 1-18, 2017.

서은정, 류시두. 딜리셔스 벅스: 미래 식량, 식용 곤충 이야기. 리잼, 서울, pp39-96, 2019.

박초희, 김경희, 육홍선. 조리 과정 중 시래기의 항산화 활성 및 항균 활성 비교. 한국식품영양학회지, 27: 609-618, 2014.

유정식, 우관식, 황인국, 이연리, 강태수, 정헌상. 번데기 가수분해물의 $\mathrm{ACE}$ 저해활성과 항산화활성. 한국식품영양과학회 지, 37: 136-140, 2008. 


\section{中文摘要}

\section{利用响应面法优化蚕、粉虫和白蛉的混合比}

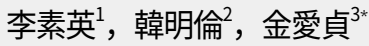

1京畿大学代替医疗大学院中疗科, 首尔, 韩国

慧田大学烘焙科学与技术学科, 忠清南道洪城郡, 韩国

3京畿大学代替医疗大学院食品治疗学科，首尔，韩国

目的：在这项研究中，为了提高昆虫食物作为改善慢性病的食物材料的利用率，使用响应面分析得出了蚕、粉 虫和蛞蝓的最佳混合比例。方法: 家蚕、粉虫、白蛉为自变量, 总BCAA含量、总不饱和脂肪酸含量、总多酚含 量、总黄酮含量、ABTS自由基清除活性、 $\alpha$-葡萄糖苷酶抑制活性、ACE抑制活性作为因变量来确定最佳混合 比。结果: 根据响应面分析得出的总 BCAA 含量、总不饱和脂肪酸含量、抗氧化活性和酶活性的最佳混合比是 蚕 $\left(X_{1}\right) 2.998$ : 粉虫 $\left(X_{2}\right) 0.623$ : 白蛴螬 $\left(X_{3}\right) 1.983$ 。在该比例下, BCAA总含量为 $0.52 \mathrm{~g}$, 不饱和脂肪酸总含量为 $0.44 \mathrm{~g}$, 多酚总含量为 $67.02 \mathrm{mg} \mathrm{TAE} / \mathrm{g}$ ，总黄酮含量为 $35.58 \mathrm{mg} \mathrm{QE} / \mathrm{g}, A B T S$ 自由基清除活性为 $95.61 \% ， \alpha$-葡 萄糖苷酶抑制活性为 $37.79 \%$, ACE抑制活性为 $95.25 \%$ 。结论: 预计本研究中得到的蚕、粉虫和白蛉的最佳混合 比例可用于开发治疗各种慢性病的产品。

关键词：昆虫食品，响应面分析，抗氧化活性， $\alpha$-葡萄糖苷酶抑制活性，ACE抑制活性 
